\title{
Intracellular Localization of Enzymes in Leaves and Chloroplast Membrane Permeability to Compounds Involved in Amino Acid Syntheses
}

\author{
Kurt A. Santarius * and C. Ralph Stocking \\ Department of Botany, University of California, Davis, California 95616, USA \\ (Z. Naturforschg. 24 b, 1170-1179 [1969]; eingegangen am 10. März 1969)
}

\begin{abstract}
1. Enzyme distribution between chloroplasts and the nonchloroplast parts of green leaf cells of Spinacia oleracea, Nicotiana rustica, Vicia faba, and Phaseolus vulgaris have been investigated by use of the nonaqueous chloroplast isolation technique. Whereas pyruvate kinase and peroxidase were located only or mainly outside of the chloroplasts, the other enzymes studied, isocitric dehydrogenase, glutathione reductase, NAD- and NADP-dependent pyridine nucleotide quinone reductase, malic dehydrogenase, NAD- and NADP-dependent glyoxylate reductase, glutamate-oxaloacetate transaminase, NAD-dependent glutamic dehydrogenase, and NADP-dependent aspartic dehydrogenase were both inside and outside of the plastids. In contrast, NADP-dependent glyceraldehyde3 -phosphate dehydrogenase is located only within the chloroplasts.

2. Intact isolated spinach chloroplasts incorporated only a very small amount of labeled carbon from ${ }^{14} \mathrm{CO}_{2}$ into amino acids in the light. The addition of $\mathrm{NH}_{4} \mathrm{Cl}$ did not increase the amount of labeled amino acids and had no effect on the total amount of ${ }^{14} \mathrm{C}$ fixed during short time photosynthesis. However, $\mathrm{NH}_{4}{ }^{\oplus}$ caused changes in the pathway of carbon during photosynthesis. In the presence of $\mathrm{NH}_{4}{ }^{\oplus}$, more ${ }^{14} \mathrm{C}$ was incorporated into sugar monophosphates and phosphoglyceric acid than in the absence of $\mathrm{NH}_{4}{ }^{\oplus}$.

$3 .{ }^{14} \mathrm{C}$-labeled glycine and serine fed to intact isolated spinach chloroplasts were neither accumulated nor transformed into other compounds, but ${ }^{14} \mathrm{C}$-labeled glutamic acid was converted into glutamine. This transformation took place only in the light in chloroplasts containing an intact outer envelope. The addition of $\mathrm{NH}_{4}{ }^{\oplus}$ and certain substrates and cofactors did not increase the rate of transformation.

4. The penetration of some amino acids and substrates through the outer envelope of the chloroplasts was investigated on aqueously isolated spinach plastids. It was found that $\alpha$-ketoglutarate, oxaloacetate, pyruvate, aspartate, and alanine are able to penetrate the envelope although at least for some of these compounds the outer membrane of the chloroplasts acts as a partial barrier.

5. From the experiments reported here and in connection with the results published by other investigators it can be concluded that the most common amino acids such as glutamic acid, aspartic acid, alanine, glycine, and serine are able to penetrate through the outer envelope of the chloroplasts and the synthesis of these amino acids can occur in the leaf cells inside as well as outside of the chloroplasts.
\end{abstract}

Although it is well known that protein synthesis occurs within the leaf cells of higher plants not only in the cytoplasm but also in the chloroplasts ${ }^{1-4}$, little information is available on the role of chloroplasts in amino acid synthesis. Rosenberg et al. ${ }^{5}$ found that aspartic acid was synthesized by isolated chloroplasts but LEECH and ELLIS ${ }^{6}$ presented evidence that this could be due to the contamination of the isolated chloroplasts by mitochondria. According

* Present Adress: Botanisches Institut der Universität Düsseldorf, 4 Düsseldorf, Ulenbergstraße 127, Germany.

1 U. Heber, Z. Naturforschg. 15 b, 100 [1960].

2 B. Parthier and R. Wollgiehn, in: P. Sitte, Probleme der biologischen Reduplikation, pg. 244, Springer-Verlag, Berlin/Heidelberg/New York 1966.

3 J. W. Davies and E. C. Cocking, Planta 76, 285 [1967].

${ }_{4}$ M. M. Margulies and F. Parenti, Plant Physiol. 43, 504 [1968].

5 L. L. Rosenberg, J. B. Capindale, and F. R. Whatley, Nature [London] 181, 632 [1958].

${ }^{6}$ R. M. Leech and R. J. Ellis, Nature [London] 190, 790 [1961].

7 U. HeBER, Habilitationsschrift, Bonn 1963. to HEBer ${ }^{7}$ part of the leaf aspartic acid and alanine seem to be synthesized in vivo in chloroplasts of higher plants, while SMITH et al. ${ }^{8}$ found evidence of amino acid synthesis by chloroplasts of Chlorella.

Considerable evidence is available for the existence of amino acids in at least two pools within the living cell. This was found in animal cells (literature by Moses $^{9}$ ), in yeast cells ${ }^{10}$, in Chlorella ${ }^{8,11}$, and in cells of higher plants ${ }^{12-14}$. The question then arises

8 D. C. Smith, J. A. Bassham, and M. Kirk, Biochim. biophysica Acta [Amsterdam] 48, 299 [1961].

9 V. Moses, in: H. Metzner, Die Zelle, pg. 248, Stuttgart 1966.

10 D. B. Cowie and F. T. McLure, Biochim. biophysica Acta [Amsterdam] 31, 236 [1959].

11 J. A. Bassham, B. Morawiecka, and M. Kirk, Biochim. biophysica Acta [Amsterdam] 90, 542 [1964].

12 A. Ongun and C. R. Stocking, Plant Physiol. 40, 819 [1965].

13 F. C. Steward and R. G. S. Bidwell, J. exp. Bot. 17, 726 [1966].

14 H. G. Aach and U. Heber, Z. Pflanzenphysiol. 57, 317 [1967]. 
concerning the permeability of the various cell membranes to different amino acids. How readily do amino acids exchange between the two or more amino acid pools in the cell?

The present paper presents results of a study (1) of the intracellular distribution of some of the enzymes that are necessary for amino acid synthesis and (2) of the permeability of the chloroplast envelope to various compounds involved in amino acid synthesis.

\section{Material and Methods}

Leaves of spinach (Spinacia oleracea L.) grown in pots in the open or bought from the local market were used. Tobacco (Nicotiana rustica L.), broad bean (Vicia faba L.), and bush bean (Phaseolus vulgaris L.) were grown in the greenhouse.

Nonaqueous isolation of chloroplasts and enzyme as. says. The intracellular distribution of enzymes was determined by isolating chloroplasts nonaqueously from tobacco and bean leaves by a modification of the method of Heber et al. ${ }^{15}$. Enzyme activities were determined on samples resuspended in ice cold $0.1 \mathrm{M} \mathrm{TRA}$ * $\left(\mathrm{pH}\right.$ 7.5). In some instances, $10^{-3} \mathrm{M}$ EDTA was included in the resuspending medium. Isocitric dehydrogenase, malic dehydrogenase, glyoxylate reductase, glutathione reductase, glyceraldehyde-3-phosphate dehydrogenase, glutamate-oxaloacetate transaminase, glutamate-pyruvate transaminase, and glutamic dehydrogenase were determined under the conditions described by BERGMEYER ${ }^{16}$. The other enzyme reactions were carried out by using the following methods: pyruvate kinase ${ }^{17}$, pyridine nucleotide quinone reductase ${ }^{18}$, peroxidase ${ }^{19}$, and aspartic dehydrogenase ${ }^{20}$. Absorption measurements were made with a Zeiss spectrophotometer. The distribution of the enzymes between the chloroplasts and the nonchloroplast part of the cell was calculated by the method of HEBER and WILLENBRINK ${ }^{21}$.

Aqueous isolation of chloroplasts. The isolation of chloroplasts from spinach leaves was performed as described by JENSEN and BASSHAM ${ }^{22}$, except that the chloroplasts were transferred, after sedimentation in buffer A, directly into buffer C, pH 7.6 ("intact" chloroplasts) or into distilled water ("broken" chloroplasts). The integrity of the intact chloroplasts was checked either microscopically or by using the amount of oxygen evolution as a criterion ${ }^{23}$. Under the micro-

15 U. Heber, N. G. Pon, and M. Heber, Plant Physiol. 38, 355 [1963].

16 H. U. Bergmeyer, Methoden der enzymatischen Analyse, Verlag Chemie, Weinheim 1962.

17 T. BüCher and G. Pfleiderer, in: Methods in Enzymology, vol. I, pg. 435, Academic Press, New York 1955.

18 W. D. Wosilait and A. Nason, ibid., vol. II, pg. 725.

19 B. Chance and A. C. Maehly, ibid., vol. II, pg. 764.

20 G. JACOBI, Planta 49, 561 [1957].

21 U. Heber and J. Willenbrink, Biochim. biophysica Acta [Amsterdam] 82, 313 [1964]. scope, the control showed between 40 and $60 \%$ of the chloroplasts in the preparation with intact outer envelopes. Oxygen evolution was determined with an oxygraph (Gilson Medical Electronics) on samples of chloroplasts in buffer $\mathrm{C}$ immediately after isolation and at the end of the main experiment. If it is taken into consideration that only 40 to $60 \%$ of the chloroplasts are intact, the activities of the intact chloroplasts were about twice that calculated on a total chlorophyll basis.

${ }^{14} \mathrm{CO}_{2}$ feeding. Incorporation of ${ }^{14} \mathrm{CO}_{2}$ into isolated chloroplasts was carried out in small centrifuge tubes in buffer $\mathrm{C}\left(\mathrm{pH} \mathrm{7.6)}\right.$ at $26^{\circ} \mathrm{C}$ under the conditions outlined in Table 4 . The total volume was 90 to $95 \mu \mathrm{l}$. After preillumination at approximately $2500 \mathrm{ft}-\mathrm{c}$. (General Electric Reflector Flood $150 \mathrm{~W}$ ) for 1 to $2 \mathrm{~min}$, $\mathrm{NaH}^{14} \mathrm{CO}_{3}$ (specific activity $5 \mathrm{mC} / \mathrm{mmol}$ ) was added. After incubation in the light for 15 to $20 \mathrm{~min}$, the chloroplasts were killed with hot $96 \%$ ethanol (final concentration $70 \%$ ).

The compounds were separated by two dimensional paper chromatography on Whatman 4 paper which was previously washed $3 \mathrm{hrs}$ in $0.5 \%$ oxalic acid and rinsed 15 times in distilled water. Chromatography was carried out in the first direction with n-butanol/ propionic $\mathrm{acid} /$ water $(47 / 23 / 30, \mathrm{v} / \mathrm{v} / \mathrm{v})$ and in the second direction with water saturated phenol. The location of the labeled compounds was determined by autoradiography and the radioactivity of the individual compounds was determined by counting the cut out paper in a liquid scintillation counter (Packard Model $500 \mathrm{E})$.

Amino acid feeding. Feeding of isolated chloroplasts (89 to $135 \mu \mathrm{g}$ chlorophyll in the glycine and serine experiments, 27 to $72 \mu \mathrm{g}$ chlorophyll in the glutamic acid experiments) was performed in the light and the dark under conditions similar to those described for ${ }^{14} \mathrm{CO}_{2}$ feeding. In some cases (see below), different amounts of cofactors or substrates were added. At zero time the labeled amino acids were added to give final concentrations as follows: glycine 1.7 to $3.2 \cdot 10^{-5} \mathrm{M}$ (specific activity $50.3 \mathrm{mC} / \mathrm{mmol}$ ), serine 1.0 to $1.9 \cdot 10^{-5} \mathrm{M}$ (specific activity $84 \mathrm{mC} / \mathrm{mmol}$ ), and glutamic acid 1.7 to $2.8 \cdot 10^{-4} \mathrm{M}$ (specific activity $10 \mathrm{mC}$ / mmol DL-glutamic-3,4-14 $\mathrm{C}$ acid). The total volume of the reaction medium was 70 to $140 \mu \mathrm{l}$. At intervals, the chloroplasts were killed with hot $96 \%$ ethanol (final concentration $70 \%$ ). In some experiments with glycine and serine, the suspensions were centrifuged for a short time in order to sediment the chloroplasts. The supernatant was transferred to another tube and hot

22 R. G. Jensen and J. A. Bassham, Proc. nat. Acad. Sci. 56, 1059 [1966].

23 J. M. Robinson and C. R. Stocking, Plant Physiol. 43, 1597 [1968].

* Abbreviations: ATP $=$ adenosine triphosphate, EDTA $=$ ethylene diamine tetraacetate, NAD = diphosphopyridine nucleotide, $\mathrm{NADP}(\mathrm{H})=$ (reduced) triphosphopyridine nucleotide, PGA = 3-phosphoglyceric acid, TRA = triethanolamine. 
ethanol was added to each tube. The weights of chloroplasts and supernatant were taken before the addition of ethanol.

Aliquots were plated in ultrathin layers on planchets and the total radioactivity determined (Nuclear Chicago Automatic Planchet Sample Changer combined with a Series Decade Scaler). The ${ }^{14}$ C-labeled compounds were separated by one dimensional paper chromatography on washed Whatman 4 paper. The following solvents were used: n-butanol/propionic acid/water $(47 / 23 / 30, \mathrm{v} / \mathrm{v} / \mathrm{v})$, isobutyric acid/ $\mathrm{NH}_{3} / \mathrm{EDTA}^{24}$, and in a few cases phenol/water $(80 / 20, \mathrm{v} / \mathrm{v})$, and pyridine/ water $(80 / 20, \mathrm{v} / \mathrm{v})$. The radioactive spots were identified by running the chromatograms through a strip counter (Vanguard Automatic Chromatogram Scanner $800)$ and the radioactivity was determined as described previously.

In some instances the distribution of radioactivity among the different compounds was checked by two dimensional paper chromatography as described above. In these cases the solvents were (1) n-butanol/propionic acid/water $(47 / 23 / 30, \mathrm{v} / \mathrm{v} / \mathrm{v})$ and $\mathrm{phenol} /$ water $(80 / 20, \mathrm{v} / \mathrm{v})$ or $(2)$ isobutyric acid/ $\mathrm{NH}_{3} / \mathrm{EDTA}^{24}$ and n-butanol/propionic acid/water (as above).

Substrate translocation. In experiments on the penetration of substrates through the chloroplast envelope in vitro, the activities of glyceraldehyde-3-phosphate dehydrogenase, glutamate-oxaloacetate transaminase, and glutamate-pyruvate transaminase were measured as described by BERGMEYER ${ }^{16}$. Substrate penetration was calculated according to the method of HEBER et al. ${ }^{25}$ in which three different preparations from each sample were used: A. broken chloroplasts which show the total activity of the enzyme in the plastids; B. "intact" chloroplasts which always contained a certain amount of broken plastids; C. the supernatant of the "intact" chloroplasts after short centrifugation of the chloroplast suspension. The stimulation rate (B-C/A-C) is a measure of the penetration of the substrates. The higher the stimulation due to plastid rupture, the more impermeable the chloroplast envelope for at least one of the involved compounds under the conditions of the experiment.

Breaking of the chloroplasts was achieved by osmotic shock or by ultrasonic vibration ( $5 \mathrm{sec}$ at full intensity; Biosonic II, Bronwill Scientific, Rochester, N.Y.).

\section{Results and Discussion}

\section{Intracellular distribution of enzymes}

\section{a) Purity of the nonaqueous chloroplasts}

The determination of the distribution of a series of enzymes between the chloroplasts and nonchloroplast part of the cell should give some information

24 E. TYSZKiewicz, Analyt. Biochem. [New York] 3, 164 [1962]. on the sites in which synthesis of different substrates can take place. The technique of isolation of chloroplasts in a nonaqueous medium from freezedried material makes possible the quantitative determination of enzyme distribution between chloroplasts and the nonchloroplast part of the cell. In some cases, it might be possible that the enzyme activity which is calculated for the nonchloroplast part of the cell is too low because of the inhibition effects which could occur in this fraction. This fraction contains all of the material which is normally located in the vacuole and, therefore, separated from the cytoplasm and the different cell organells in the intact cell. Vacuolar compounds when mixed with the cytoplasm could inhibit at least a part of the enzyme reactions. However, even if this should be the case, the results should still show at least whether an enzyme is located only outside of the chloroplasts or in both compartments, inside and outside of the plastids.

The prerequisite for obtaining reliable results is the isolation of a chloroplast fraction which is relatively free from contamination by cytoplasm, mitochondria, or other cell material. The purity of the isolated chloroplasts may be checked by testing for enzymes absent in vivo from the chloroplasts, e. g. pyruvate kinase ${ }^{1}$. Table 1 shows the distribution of pyruvate kinase in the separated material which was used for the further enzyme studies. Since in all cases less than $10 \%$ of the pyruvate kinase was found in the chloroplast fractions, it may be concluded that the contamination of the isolated plastids by cytoplasmic material was less than 10 per cent.

Since the pyruvate kinase is sometimes inhibited in the total leaf extracts, efforts were made to find other enzymes which are located only outside of the chloroplasts and thus can be used as a measure of cytoplasmic contamination of the isolated plastids. SMILLIE ${ }^{26}$ found, for instance, in Euglena that isocitric dehydrogenase and glutathione reductase both appear to be located only outside the chloroplasts. Our results (Table 1) indicate that these enzymes and in addition pyridine nucleotide quinone reductase were present both in the chloroplasts and the nonchloroplast samples obtained from the leaves of the higher plants tested.

25 U. Heber, U. W. Hallier, and M. A. Hudson, Z. Naturforschg. 22 b, 1200 [1967].

26 R. M. Smillie, Canad. J. Bot. 41, 123 [1963]. 


\begin{tabular}{|c|c|c|c|c|c|c|c|c|c|c|c|c|}
\hline \multirow[b]{3}{*}{ Nr. } & \multirow[b]{3}{*}{ plant } & \multirow[b]{3}{*}{ fraction } & \multirow{2}{*}{\multicolumn{2}{|c|}{$\begin{array}{l}\text { pyruvate } \\
\text { kinase }\end{array}$}} & \multirow{2}{*}{\multicolumn{2}{|c|}{$\begin{array}{c}\text { isocitric } \\
\text { dehydrogenase }\end{array}$}} & \multirow{2}{*}{\multicolumn{2}{|c|}{$\begin{array}{l}\text { glutathione } \\
\text { reductase }\end{array}$}} & \multicolumn{4}{|c|}{$\begin{array}{c}\text { pyridine nucleotide quinone } \\
\text { reductase }\end{array}$} \\
\hline & & & & & & & & & \multicolumn{4}{|c|}{ NAD-dependent NADP-dependent } \\
\hline & & & 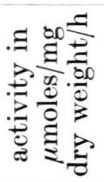 & 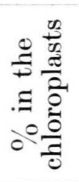 & 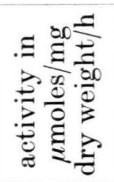 & 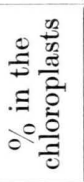 & 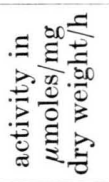 & 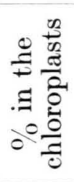 & 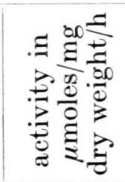 & 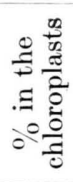 & 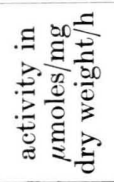 & $\begin{array}{l}\frac{0}{\frac{\pi}{0}} \\
\frac{\pi}{0} \\
. \Xi \frac{0}{0} \\
0 \frac{0}{0}\end{array}$ \\
\hline \multirow[t]{2}{*}{1} & Vicia & chloroplasts & 0.008 & 2.2 & 0.34 & 19 & 1.52 & 56 & 1.37 & 12 & 3.47 & 67 \\
\hline & Vicia & $\begin{array}{l}\text { nonchl. parts } \\
\text { chloroplasts }\end{array}$ & $\begin{array}{l}0.214 \\
0.009\end{array}$ & 2.6 & $\begin{array}{l}0.76 \\
0.42\end{array}$ & 29 & $\begin{array}{l}0.76 \\
1.44\end{array}$ & 70 & $\begin{array}{l}6.13 \\
1.39\end{array}$ & 17 & $\begin{array}{l}1.08 \\
3.92\end{array}$ & 68 \\
\hline 2 & & nonchl. parts & 0.280 & & 0.85 & & 0.52 & & 5.53 & & 0.75 & \\
\hline \multirow[t]{2}{*}{3} & Vicia & chloroplasts & - & - & 0.50 & 31 & - & - & 1.82 & 20 & 3.51 & 65 \\
\hline & & nonchl. parts & - & - & 0.71 & & - & & 4.57 & & 1.18 & \\
\hline \multirow[t]{2}{*}{4} & Nicotiana & chloroplasts & 0.009 & 3.5 & 0.40 & 38 & 0.57 & 97 & 2.98 & 34 & 5.46 & 56 \\
\hline & & nonchl. parts & 0.135 & & 0.36 & & 0.025 & & 3.28 & & 2.41 & \\
\hline 5 & Nicotiana & chloroplasts & 0.016 & 5.7 & 0.44 & 52 & 0.77 & 109 & $\begin{array}{l}2.95 \\
383\end{array}$ & 27 & 6.11 & 47 \\
\hline \multirow[t]{2}{*}{6} & Phaseolus & $\begin{array}{l}\text { nonchl. parts } \\
\text { chloroplasts }\end{array}$ & $\begin{array}{l}0.132 \\
0.026\end{array}$ & 8.1 & $\begin{array}{l}0.20 \\
0.27\end{array}$ & 29 & $\begin{array}{l}0.00 \\
0.67\end{array}$ & 57 & $\begin{array}{l}3.83 \\
3.45\end{array}$ & 40 & $\begin{array}{l}3.40 \\
4.72\end{array}$ & 53 \\
\hline & & nonchl. parts & 0.268 & & 0.60 & & 0.46 & & 4.65 & & 3.79 & \\
\hline
\end{tabular}

Table 1. The distribution of pyruvate kinase, isocitric dehydrogenase, glutathione reductase, NAD-dependent and NADPdependent pyridine nucleotide quinone reductase between the chloroplasts and the nonchloroplast parts of green leaf cells.

\begin{tabular}{|c|c|c|c|c|c|c|c|c|c|c|c|c|}
\hline \multirow[b]{3}{*}{ Nr. } & \multirow[b]{3}{*}{ plant } & \multirow[b]{3}{*}{ fraction } & \multirow{2}{*}{\multicolumn{2}{|c|}{ peroxidase }} & \multirow{2}{*}{\multicolumn{2}{|c|}{$\begin{array}{c}\text { glyceraldehyde- } \\
\text { 3-phosphate } \\
\text { dehydrogenase }\end{array}$}} & \multirow{2}{*}{\multicolumn{2}{|c|}{$\begin{array}{c}\text { malic } \\
\text { dehydrogenase }\end{array}$}} & \multicolumn{4}{|c|}{ glyoxylate reductase } \\
\hline & & & & & & & & & \multicolumn{2}{|c|}{$\begin{array}{c}\text { NAD- } \\
\text { dependent }\end{array}$} & \multicolumn{2}{|c|}{$\begin{array}{l}\text { NADP- } \\
\text { dependent }\end{array}$} \\
\hline & & & 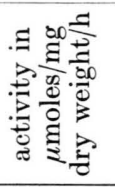 & 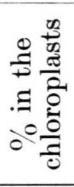 & 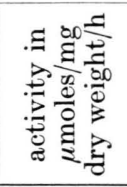 & 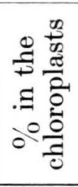 & 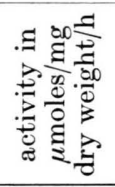 & 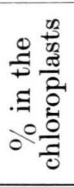 & 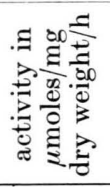 & 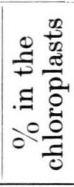 & 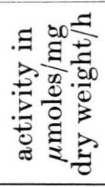 & 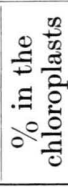 \\
\hline 1 & Vicia & $\begin{array}{l}\text { chloroplasts } \\
\text { nonchloro. parts }\end{array}$ & $\begin{array}{r}9.3 \\
78.6\end{array}$ & 7.0 & $\begin{array}{l}4.40 \\
0.04\end{array}$ & 99 & $\begin{array}{l}16.0 \\
30.9\end{array}$ & 22 & $\begin{array}{l}0.61 \\
1.20\end{array}$ & 24 & $\begin{array}{l}0.216 \\
0.208\end{array}$ & 40 \\
\hline 2 & Vicia & $\begin{array}{l}\text { chloroplasts } \\
\text { nonchloro. parts }\end{array}$ & $\begin{array}{l}12.2 \\
70.0\end{array}$ & 12.6 & $\begin{array}{l}4.12 \\
0.00\end{array}$ & 102 & $\begin{array}{l}19.8 \\
41.1\end{array}$ & 28 & $\begin{array}{l}0.53 \\
1.26\end{array}$ & 26 & $\begin{array}{l}0.173 \\
0.226\end{array}$ & 46 \\
\hline 3 & Vicia & $\begin{array}{l}\text { chloroplasts } \\
\text { nonchloro. parts }\end{array}$ & $\begin{array}{r}6.7 \\
69.0\end{array}$ & 5.7 & $\begin{array}{l}8.49 \\
0.00\end{array}$ & 102 & $\begin{array}{l}20.7 \\
43.8\end{array}$ & 23 & - & - & - & - \\
\hline 4 & Nicotiana & $\begin{array}{l}\text { chloroplasts } \\
\text { nonchloro. parts }\end{array}$ & $\begin{array}{l}\text { inhib. } \\
\text { inhib. }\end{array}$ & - & inhib. & - & $\begin{array}{l}25.6 \\
29.4\end{array}$ & 33 & $\begin{array}{l}1.25 \\
1.80\end{array}$ & 28 & $\begin{array}{l}0.193 \\
\text { inhib. }\end{array}$ & - \\
\hline 5 & Nicotiana & $\begin{array}{l}\text { chloroplasts } \\
\text { nonchloro. parts }\end{array}$ & $\begin{array}{l}\text { inhib. } \\
\text { inhib. }\end{array}$ & - & inhib. & - & $\begin{array}{l}30.1 \\
18.2\end{array}$ & 45 & $\begin{array}{l}1.70 \\
2.21\end{array}$ & 27 & $\begin{array}{l}0.282 \\
\text { inhib. }\end{array}$ & - \\
\hline 6 & Phaseolus & $\begin{array}{l}\text { chloroplasts } \\
\text { nonchloro. parts }\end{array}$ & $\begin{array}{r}4.7 \\
142.0\end{array}$ & 2.9 & $\begin{array}{l}4.50 \\
0.00\end{array}$ & 128 & $\begin{array}{l}23.2 \\
45.8\end{array}$ & 31 & $\begin{array}{l}1.33 \\
0.89\end{array}$ & 57 & $\begin{array}{l}0.213 \\
0.059\end{array}$ & 78 \\
\hline
\end{tabular}

Table 2. The distribution of peroxidase, NADP-dependent glyceraldehyde-3-phosphate dehydrogenase, malic dehydrogenase, NAD-dependent and NADP-dependent glyoxylate reductase between the chloroplasts and the nonchloroplast parts of green leaf cells.

In contrast, peroxidase (Table 2) was located in the nonchloroplast fraction of the cells and the small amount of activity associated with the plastids could have been due to the cytoplasmic contamination (compare the pyruvate kinase activity of the same samples). The peroxidase activity was relatively high, but decreased rapidly during the first minutes after the $\mathrm{H}_{2} \mathrm{O}_{2}$ was added, especially in the freeze. dried tobacco leaves. On the basis of these results, peroxidase activity could be used for measuring the contamination of the isolated chloroplasts by nonplastid cytoplasmic material in preparations from Vicia and Phaseolus leaves.

In contrast to the peroxidase activity, NADPdependent glyceraldehyde-3-phosphate dehydrogenase was found only in the chloroplasts (Table 2). This is in agreement with the results of other laboratories ${ }^{15,26}$. Besides constituting evidence of an intracellular compartmentation of this enzyme, the results also show that no secondary translocation 
across the chloroplast membrane has taken place during the nonaqueous isolation procedure.

On the basis of the results of the distribution of pyruvate kinase, peroxidase, and glyceraldehyde-3phasphate dehydrogenase (Tables 1,2 ) it can be concluded that the chloroplasts which were isolated from the freezedried leaf material contained definitly less than $15 \%$ and probably less than $10 \%$ contamination by nonplastid cytoplasmic material.

\section{b) Enzymes involved in amino acid synthesis}

In the following, the intracellular distributions of some enzymes which are involved in the synthesis of amino acids have been investigated. The results are given in Tables 2 and 3.

Malic dehydrogenase and glyoxylate reductase are enzymes which catalyze the synthesis of amino acid precursors, e.g. oxaloacetic acid and glyoxylic acid. According to SMillie ${ }^{26}$, in Euglena these enzymes appear to be located only outside the chloroplasts. As is evident from Table 2, our results indicate that malic dehydrogenase and both glyoxylate reductases are present in the chloroplasts and the nonchloroplast part of the cell. In Vicia, tobacco, and Phaseolus, about 20 to $45 \%$ of the malic dehydrogenase were found in the chloroplasts. Data of HEBER $^{1}$ also show that a considerable amount of the total malic dehydrogenase of leaf cells resides in the plastids. In contrast, YAMAZAKI and TOLBERT ${ }^{27}$ concludes that malic dehydrogenase is not located in the plastids but in mitochondria and in the peroxisomes. Table 2 also shows that peroxidase activity associated with the chloroplast fraction was within the same range as the pyruvate kinase activity and on this basis it could be concluded that in these plants peroxidase was absent from the plastids.

A variable amount of glyoxylate reductase was found associated with the plastids in the different samples of leaves tested. The NAD-dependent glyoxylate reductase activity was over $70 \%$ outside of the chloroplast samples (except in Phaseolus) while more than $40 \%$ of the NADP-dependent glyoxylate reductase was located in the chloroplast samples. TOlbert et al. ${ }^{28}$ found up to $55 \%$ of the NAD. dependent but no NADP-dependent glyoxylate reductase in spinach leaf peroxisomes.

The two transaminases tested, glutamate-oxaloacetate transaminase and glutamate-pyruvate transaminase, showed activity both inside and outside of the chloroplasts although only a low percentage of the total glutamate-pyruvate transaminase activity was associated with the chloroplasts. These results are in agreement with the results published by

\begin{tabular}{|c|c|c|c|c|c|c|c|c|c|c|}
\hline \multirow[b]{2}{*}{ Nr. } & \multirow[b]{2}{*}{ plant } & \multirow[b]{2}{*}{ fraction } & \multicolumn{2}{|c|}{$\begin{array}{l}\text { glutamate- } \\
\text { oxaloacetate } \\
\text { transaminase }\end{array}$} & \multicolumn{2}{|c|}{$\begin{array}{l}\text { glutamate- } \\
\text { pyruvate } \\
\text { transaminase }\end{array}$} & \multicolumn{2}{|c|}{$\begin{array}{l}\text { NAD-dependent } \\
\text { glutamic } \\
\text { dehydrogenase }\end{array}$} & \multicolumn{2}{|c|}{$\begin{array}{c}\text { NADP-dependent } \\
\text { aspartic } \\
\text { dehydrogenase }\end{array}$} \\
\hline & & & 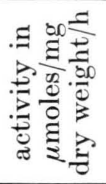 & 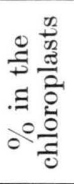 & 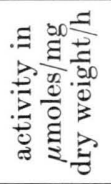 & 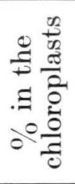 & 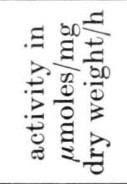 & 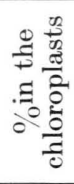 & 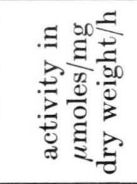 & 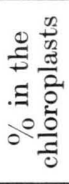 \\
\hline 1 & Vicia & $\begin{array}{l}\text { chloroplasts } \\
\text { nonchloroplast parts }\end{array}$ & $\begin{array}{l}1.36 \\
1.42\end{array}$ & 38 & $\begin{array}{l}1.27 \\
3.26\end{array}$ & 20 & $\begin{array}{l}0.010 \\
0.031\end{array}$ & 16 & $\begin{array}{l}0.026 \\
0.059\end{array}$ & 22 \\
\hline 2 & Vicia & $\begin{array}{l}\text { chloroplasts } \\
\text { nonchloroplast parts }\end{array}$ & $\begin{array}{l}1.28 \\
1.53\end{array}$ & 41 & $\begin{array}{l}1.40 \\
3.35\end{array}$ & 26 & $\begin{array}{l}0.014 \\
0.032\end{array}$ & 27 & $\begin{array}{l}0.019 \\
0.060\end{array}$ & 20 \\
\hline 3 & Vicia & $\begin{array}{l}\text { chloroplasts } \\
\text { nonchloroplast parts }\end{array}$ & $\begin{array}{l}1.39 \\
1.50\end{array}$ & 38 & $\begin{array}{l}0.95 \\
2.10\end{array}$ & 22 & - & - & - & - \\
\hline 4 & Nicotiana & $\begin{array}{l}\text { chloroplasts } \\
\text { nonchloroplast parts }\end{array}$ & $\begin{array}{l}1.66 \\
1.32\end{array}$ & 42 & $\begin{array}{l}1.47 \\
\text { inhib. }\end{array}$ & - & $\begin{array}{l}0.023 \\
0.039\end{array}$ & 25 & $\begin{array}{l}0.000 \\
0.000\end{array}$ & - \\
\hline 5 & Nicotiana & $\begin{array}{l}\text { chloroplasts } \\
\text { nonchloroplast parts }\end{array}$ & $\begin{array}{l}1.64 \\
1.59\end{array}$ & 34 & $\begin{array}{l}1.75 \\
\text { inhib. }\end{array}$ & - & $\begin{array}{l}0.010 \\
0.052\end{array}$ & 8 & $\begin{array}{l}0.057 \\
0.000\end{array}$ & - \\
\hline 6 & Phaseolus & $\begin{array}{l}\text { chloroplasts } \\
\text { nonchloroplast parts }\end{array}$ & $\begin{array}{l}1.36 \\
0.91\end{array}$ & 57 & $\begin{array}{l}0.65 \\
0.42\end{array}$ & 58 & $\begin{array}{l}0.000 \\
0.000\end{array}$ & - & $\begin{array}{l}0.053 \\
0.030\end{array}$ & 63 \\
\hline
\end{tabular}

Table 3. The distribution of glutamate-oxaloacetate transaminase, glutamate-pyruvate transaminase, NAD-dependent glutamic dehydrogenase and NADP-dependent aspartic dehydrogenase between the chloroplasts and the nonchloroplast parts of green leaf cells.

27 R. K. Yamazaki and N. E. Tolbert, Plant Physiol. 43, Suppl. 9 [1968].
28 N. E. Tolbert, A. Oeser, T. Kisaki, R. H. Hageman, and R. K. Yamazaki, J. biol. Chemistry 243, 5179 [1968]. 
WILSON et al. ${ }^{29}$ who found that transaminase activity was present in medium particles and in the corresponding supernatant. In contrast, HEBER ${ }^{1}$ reported for Vicia leaves that glutamate-pyruvate transaminase was located only outside the plastids, while glutamate-oxaloacetate transaminase was found in both fractions. KASPAREK ${ }^{30}$ has reported that barley contain transaminases capable of transferring amino groups from 16 amino acids to pyruvate. Other transaminases which were tested by the technique of $\mathrm{JACOBI}^{20}$ showed no activity in the freezedried material.

Although the total activity of both NAD-dependent glutamic dehydrogenase and NADP-dependent aspartic dehydrogenase was low, a small but significant percentage (16 to $27 \%$ ) of the total activity of these enzymes was associated with the chloroplast fraction in Vicia. The values are too high to be explained by the low cytoplasmic contamination of the chloroplast fraction indicated by the pyruvate kinase and peroxidase data and show in contrast to reports of other laboratories ${ }^{1,31}$ that low levels of these enzymes occur in the chloroplasts. LEECH and KIRK ${ }^{32}$ have recently reported a NADP-dependent L-glutamic dehydrogenase to be located exclusively in Vicia chloroplast lamellae and suggest that the NAD-dependent dehydrogenase is localized in mitochondria.

In summary none of the enzymes involved in amino acid metabolism that showed significant activity in the employed test system was absent from the plastids. On this basis alone the possibility of amino acid synthesis both inside and outside of the chloroplasts must be considered.

$$
\begin{aligned}
& { }^{14} \mathrm{CO}_{2} \text { metabolism by isolated } \\
& \text { chloroplasts }
\end{aligned}
$$

Fixation of ${ }^{14} \mathrm{C}$-labeled carbon dioxide by isolated chloroplasts has been reported by many investigators ${ }^{22,33,34}$. In general, most of the reduced ${ }^{14} \mathrm{C}$ in isolated chloroplasts is incorporated into inter-

29 D. G. Wilson, K. W. King, and R. H. Burris, J. biol. Chemistry 208, 863 [1954].

30 M. Kasparek, Physiol. Vég. 6, 19 [1968].

31 G. L. Ritenour, K. W. Joy, J. Bunning, and R. H. HageMAN, Plant Physiol. 42, 233 [1967].

32 R. M. LeECH and P. R. Kirk, Biochem. biophysic. Res. Commun. 32, 685 [1968].

33 M. Gibbs and N. Calo, Plant Physiol. 34, 318 [1959].

34 M. Losada, A. V. Trebst, and D. I. Arnon, J. biol. Chemistry 235, 832 [1960]. mediates of the carbon reduction cycle, particularly PGA, dihydroxyacetone phosphate, sugar phosphates, and glycolic acid. The labeling of secondary products of low molecular weight, for instance of amino acids, is rather small. ROSENBERG et al. ${ }^{5}$ found that at least aspartic acid can be synthesized in isolated chloroplasts, but LEECH and ELLIS ${ }^{6}$ suggested that this result may have been due to a contamination of the chloroplast preparation with mitochondria. Heber ${ }^{7}$ and Everson et al. ${ }^{35}$ observed that aspartic acid and alanine are synthesized during photosynthesis by isolated chloroplasts and TOLBERT et al. ${ }^{36,37}$ obtained ${ }^{14} \mathrm{C}$-labeling of glycine and serine in isolated plastids. Recently it was found that Acetabularia chloroplasts fed with ${ }^{14} \mathrm{CO}_{2}$ synthesize aspartic acid, glutamic acid, alanine, serine and glycine ${ }^{38}$.

The ammonium ion stimulated the incorporation of ${ }^{14} \mathrm{CO}_{2}$ into amino acids in Chlorella in vivo ${ }^{39}$. We have studied whether an excess of $\mathrm{NH}_{4}{ }^{\oplus}$ (final concentration $0.01 \mathrm{M} \mathrm{NH}_{4} \mathrm{Cl}$ ) caused a change in the pattern of ${ }^{14} \mathrm{C}$-labeled compounds formed during photosynthesis in isolated spinach chloroplasts. Fig. 1 shows the total fixation of ${ }^{14} \mathrm{C}$ into organic compounds during photosynthesis of isolated chloroplasts. During the first 5 to $10 \mathrm{~min}$, incorporation occured more or less linearly. Although rates of only 10 to $16 \mu$ moles $\mathrm{CO}_{2} / \mathrm{mg}$ chlorophyll $\cdot \mathrm{hr}$ were obtained for the first $8 \mathrm{~min}$ of this experiment, the actual rates must have been at least double this amount since only intact chloroplasts are able to fix $\mathrm{CO}_{2}$ under the conditions of the experiments ${ }^{23,40,41}$. Only about 40 to $60 \%$ of the total chlorophyll in these preparations is in the intact plastids. No difference was observed in the amount of ${ }^{14} \mathrm{C}$ incorporation in the presence or in the absence of $0.01 \mathrm{M}$ $\mathrm{NH}_{4} \mathrm{Cl}$ (Table 4).

However the presence of $0.01 \mathrm{M} \mathrm{NH}_{4}{ }^{\oplus}$ does cause a change in the pathway of carbon during photosynthesis (Table 4). In the presence of a high concentration of $\mathrm{NH}_{4}{ }^{\oplus}$, much more ${ }^{14} \mathrm{C}$ was incorporated into sugar monophosphates and especially into PGA.

35 R. G. Everson, W. Cockburn, and M. Gibbs, Plant Physiol. 42, 840 [1967].

36 W. H. Chang and N. E. Tolbert, Plant Physiol. 40, 1048 [1965].

37 P. C. Kearney and N. E. Tolbert, Arch. Biochem. Biophysics 98, 164 [1962].

38 D. C. Shephard, W. B. Levin, and R. G. S. Bidwell, Biochem. biophysic. Res. Commun. 32, 413 [1968].

39 R. G. Hiller and C. P. Whittingham, J. exp. Bot. 15, 21 [1964]. 


\begin{tabular}{|c|c|c|c|c|c|c|c|c|c|}
\hline \multicolumn{2}{|r|}{ experiment $\mathrm{Nr}$. } & \multicolumn{2}{|c|}{$\mathrm{R} 7$} & \multicolumn{2}{|c|}{ R 9} & \multicolumn{2}{|c|}{ R 11} & \multicolumn{2}{|c|}{ R 12} \\
\hline \multirow{6}{*}{ 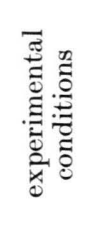 } & $\mathrm{NaH}^{14} \mathrm{CO}_{3}\left(10^{-3} \mathrm{M}\right)$ & \multirow{2}{*}{\multicolumn{2}{|c|}{$\begin{array}{c}4.2 \\
0\end{array}$}} & \multirow{2}{*}{\multicolumn{2}{|c|}{$\begin{array}{l}5.5 \\
1.3\end{array}$}} & \multirow{2}{*}{\multicolumn{2}{|c|}{$\begin{array}{l}5.9 \\
1.3\end{array}$}} & \multirow{2}{*}{\multicolumn{2}{|c|}{6.2}} \\
\hline & pyridoxal phosphate $\left(10^{-3} \mathrm{M}\right)$ & & & & & & & & \\
\hline & $\mathrm{NH}_{4} \mathrm{Cl}\left(10^{-2} \mathrm{M}\right)$ & 0 & 1.0 & 0 & 1.0 & 0 & 1.0 & 0 & 1.0 \\
\hline & chlorophyll $(\mathrm{mg} / \mathrm{ml})$ & \multirow{2}{*}{\multicolumn{2}{|c|}{$\begin{array}{l}0.56 \\
20\end{array}$}} & \multirow{2}{*}{\multicolumn{2}{|c|}{$\begin{array}{l}0.64 \\
20\end{array}$}} & \multirow{2}{*}{\multicolumn{2}{|c|}{$\begin{array}{l}0.425 \\
15\end{array}$}} & \multirow{2}{*}{\multicolumn{2}{|c|}{$\begin{array}{c}0.40 \\
16\end{array}$}} \\
\hline & photosynthesis (min) & & & & & & & & \\
\hline & $\begin{array}{l}\text { rate of photosynthesis } \\
(\mu \text { moles/mg chlorophyll } \cdot \mathrm{h})\end{array}$ & 4.1 & 3.9 & 2.8 & 3.5 & 10.8 & 11.6 & 9.3 & 9.0 \\
\hline$\dot{0} 0$ & sugar diphosphates & 31.8 & 23.1 & 13.7 & 9.1 & 26.8 & 12.4 & 14.0 & 5.0 \\
\hline$\because \frac{\pi}{\square}$ & sugar monophosphates & 5.9 & 9.2 & 5.3 & 7.5 & 4.4 & 10.4 & 8.9 & 22.8 \\
\hline$\Xi \Xi$ & dihydroxyacetone phosphate & 29.5 & 22.4 & 45.6 & 33.9 & 7.7 & 9.5 & 24.4 & 11.7 \\
\hline$g \overline{0}$ & phosphoglyceric acid & 3.3 & 17.4 & 4.6 & 20.7 & 18.9 & 40.6 & 19.5 & 37.1 \\
\hline$\pm \frac{1}{2}$ & aspartic acid & 0.9 & 1.3 & 1.8 & 1.8 & 1.2 & 0.9 & 0.4 & 0.4 \\
\hline 0.0 & glycine & 14.5 & 9.1 & 6.0 & 5.5 & 8.4 & 4.1 & 8.1 & 2.9 \\
\hline$a^{0}$ & alanine & 1.7 & 1.6 & 1.8 & 1.6 & 2.0 & 1.5 & 1.0 & 0.8 \\
\hline
\end{tabular}

Table 4. Incorporation of ${ }^{14} \mathrm{C}$ into various compounds during photosynthesis of intact spinach chloroplasts with ${ }^{14} \mathrm{CO}_{2}$ in the presence and absence of $\mathrm{NH}_{4} \mathrm{Cl}$.

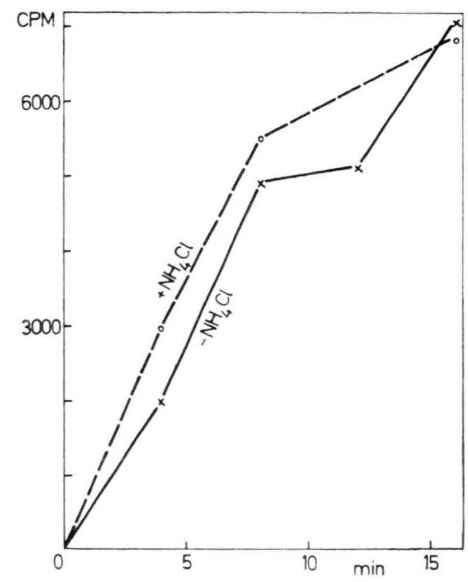

Fig. 1. The total amount of ${ }^{14} \mathrm{C}$-labeled products after photosynthesis of intact isolated spinach chloroplasts with ${ }^{14} \mathrm{CO}_{2}$ in the presence and absence of $\mathrm{NH}_{4} \mathrm{Cl}$. Abscissa: time in min. Ordinate: total amount of ${ }^{14} \mathrm{C}$-labeled compounds in counts per min per $\mu \mathrm{g}$ chlorophyll.

In contrast, a much smaller amount of ${ }^{14} \mathrm{C}$ was found in the sugar diphosphates (including uridine diphosphoglucose) while the synthesis of dihydroxyacetone phosphate decreased only slightly under the conditions of the experiment.

After 15 to 20 min of photosynthesis in isolated chloroplasts, significant labelling was found in aspartic acid, alanine, and glycine. In the presence of $0.01 \mathrm{M} \mathrm{NH}_{4}{ }^{\oplus}$, glycine and to a lesser extent alanine labelling was reduced.

40 D. A. WAlker and R. Hill, Biochim. biophysica Acta [Amsterdam] 131, 330 [1967].

41 J. A. Bassham, M. Kirk, and R. G. Jensen, Biochim. biophysica Acta [Amsterdam] 153, 211 [1968].

42 E. Jimenez, R. L. Baldin, N. E. Tolbert, and W. A. WOOD, Arch. biochem. Biophysics 98, 172 [1962].
These findings confirm the previous reports that chloroplasts can synthesize at least several of the most common amino acids.

3. Metabolism of ${ }^{14} \mathrm{C}-\mathrm{l}$ abeled amino acids fed to isolated chloroplasts

Many experiments have been made in which ${ }^{14} \mathrm{C}$ labeled amino acids have been fed to leaf cells in vivo. For example JimeneZ et al. ${ }^{42}$ found that in wheat leaves ${ }^{14} \mathrm{C}$-labeled serine was converted into sucrose in the light. In addition ONGUN and STOCKING ${ }^{12}$ observed that ${ }^{14} \mathrm{C}$-labeled serine moves rapidly into chloroplasts when fed to detached tobacco leaves; however, rapid metabolism of the serine took place only in the light. NAYLOR and TOlberT ${ }^{43}$ fed ${ }^{14} \mathrm{C}$ labeled glutamic acid to barley leaves and found that it was converted into glutamine, aspartate, malate, citrate, and $\gamma$-aminobutyric acid. Also these reactions were associated with the metabolism in the light.

In contrast, little work has been done in which intact isolated chloroplasts have been fed amino acids to determine the permeability properties of the plastid envelope to amino acids. SISSAKIAN ${ }^{44}$ found that labeled glycine was incorporated into protein in a chloroplast preparation although the extent of whole chloroplasts in the preparation was not determined. Chan and Bassham ${ }^{45}$ fed ${ }^{14} \mathrm{C}$-glycolic acid to chloroplasts and obtained glycine.

43 A. W. Naylor and N. E. Tolbert, Physiol. Plant. 9, 220 [1956].

44 N. M. Sissakian, Proc. Intern. Congr. Biochem., 3rd Congr., Brussels 1955, pg. 13, Acad. Press, New York 1956.

${ }^{45}$ H. W. S. Chan and J. A. Bassham, Biochim. biophysica Acta [Amsterdam] 141, 426 [1967]. 
In an attempt to determine whether certain amino acids were able to penetrate into intact chloroplasts and either be accumulated there or transformed within the plastids, ${ }^{14} \mathrm{C}$-glycine, ${ }^{14} \mathrm{C}$-serine, and ${ }^{14} \mathrm{C}$ glutamic acid were fed to isolated chloroplasts which were provided with or without cofactors (e.g. pyridine phosphate, pyridine nucleotides, ATP), substrates (e.g. pyruvate, oxaloacetate), $\mathrm{NH}_{4}{ }^{\oplus}$, and $\mathrm{NO}_{3}{ }^{\ominus}$. In no case was either glycine or serine accumulated or transformed either in the light or in the dark after 15 to $20 \mathrm{~min}$ in these experiments. These results are surprising in view of the finding that in intact leaves these amino acids are rapidly metabolized in the light ${ }^{12,42}$.

On the other hand, exogenously fed glutamic acid is rapidly converted to glutamine by intact spinach chloroplasts in the light but not in the dark (Fig. 2).

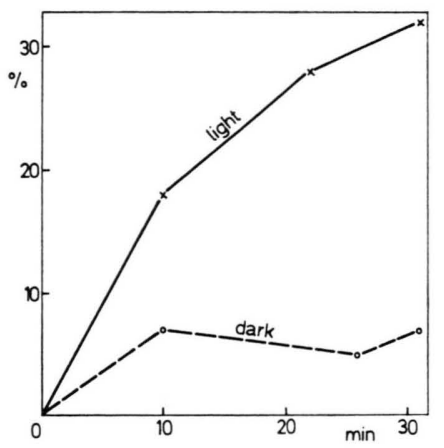

Fig. 2. Feeding of ${ }^{14} \mathrm{C}$-glutamic acid to intact isolated spinach chloroplasts in the light and in the dark. Reaction mixture: buffer $\mathrm{C}$ contains $1.9 \cdot 10^{-4} \mathrm{M}$ glutamic acid and $0.47 \mathrm{mg}$ chlorophyll $/ \mathrm{ml}$. Abscissa: time in min. Ordinate: $\%$ of the total amount of glutamic acid changed to glutamin.

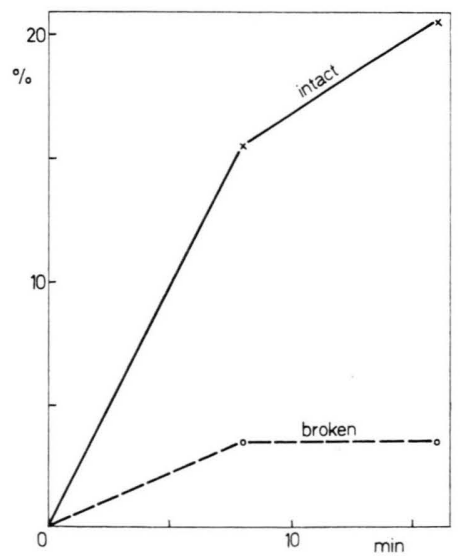

Fig. 3. Feeding of ${ }^{14} \mathrm{C}$-glutamic acid to intact and broken chloroplasts in the light. Reaction mixture: buffer C contains $2.8 \cdot 10^{-4} \mathrm{M}$ glutamic acid and $0.45 \mathrm{mg}$ chlorophyll $/ \mathrm{ml}$. Abscissa: time in min. Ordinate: $\%$ of the total amount of glutamic acid changed to glutamin.
The ${ }^{14} \mathrm{C}$ from the added glutamic acid only appeared as glutamine. When the chloroplasts were swollen in dilute buffer to break the outer envelope, they lost their ability to transform glutamic acid into glutamine (Fig. 3). These results indicate that exogenous glutamic acid can penetrate rapidly into intact chloroplasts and that the enzyme system necessary for the transformation of glutamic acid to glutamine in the light is present in the chloroplasts.

\section{Penetration of substratesthrough the chloroplast envelope}

Little is known about the in vivo permeability of the chloroplast envelope to amino acids and precursors that are necessary for amino acid synthesis. ONGUn and Stocking ${ }^{12}$, who fed labeled serine to tobacco leaves, found that at least serine moved freely through the chloroplast envelope. AACH and HEBER ${ }^{14}$ observed that there is a compartmentation at least for certain amino acids within the cell, but ${ }^{14} \mathrm{C}$-aspartic acid, ${ }^{14} \mathrm{C}$-serine, and ${ }^{14} \mathrm{C}$-alanine showed, after short time labeling with ${ }^{14} \mathrm{C}$, about the same distribution between chloroplasts and the nonchloroplast part of the cell as the nonlabeled forms. From this they concluded that at least these amino acids can penetrate easily through the chloroplast envelope.

In the present study, the penetration of some amino acids and substrates was investigated on the assumption that in intact isolated chloroplasts, an enzyme reaction proceeds only as long as all the substrates and cofactors which are necessary for the reaction are present in the plastids, and that in order for exogenously added substrates effectively to stimulate the reaction they must pass through the chloroplast envelope. Therefore, the rate of an enzyme reaction in vitro in intact chloroplasts compared to the rate in broken plastids, where there would be no permeability barrier, should give some information about the permeability of the outer envelope of the plastids to the substrates and cofactors that are originally absent from or in limiting amounts in the intact isolated plastids.

Table 5 shows that the activity of both glutamateoxaloacetate transaminase and glutamate-pyruvate transaminase was 2 to 5 times higher on a total chlorophyll basis in the preparation where all of the chloroplasts were broken than when the preparation contained some intact as well as broken plastids. In contrast, the activity of glyceraldehyde-3-phosphate 


\begin{tabular}{|c|c|c|c|c|c|c|}
\hline \multirow{2}{*}{$\begin{array}{l}\text { experiment } \\
\text { Nr. }\end{array}$} & \multicolumn{2}{|c|}{$\begin{array}{c}\text { glutamate-oxaloacetate } \\
\text { transaminase }\end{array}$} & \multicolumn{2}{|c|}{$\begin{array}{c}\text { glutamate-pyruvate } \\
\text { transaminase }\end{array}$} & \multicolumn{2}{|c|}{$\begin{array}{c}\text { NADP-dependent glyceral- } \\
\text { deyhde-3-phosphate } \\
\text { dehydrogenase }\end{array}$} \\
\hline & activity $*$ & stimulation & activity * & stimulation & activity * & stimulation \\
\hline $\begin{array}{l}1 \\
2 \\
3 \\
4\end{array}$ & $\begin{array}{l}30 \\
31 \\
37 \\
41\end{array}$ & $\begin{array}{l}2.5 \\
2.4 \\
3.1 \\
3.4\end{array}$ & $\begin{array}{r}10 \\
10 \\
8 \\
11\end{array}$ & $\begin{array}{l}4.9 \\
2.6 \\
3.7 \\
2.9\end{array}$ & $\begin{array}{c}149 \\
- \\
165 \\
262\end{array}$ & $\begin{array}{l}\infty \\
\overline{22} \\
42\end{array}$ \\
\hline
\end{tabular}

Table 5. Comparison between enzyme activities of intact and osmotically shocked spinach chloroplasts. The stimulation rate shows how much faster the enzyme reactions occur after the destruction of the outer envelope of the chloroplasts. * Enzyme activity of the shocked chloroplasts in $\mu$ moles $/ \mathrm{mg}$ chlorophyll $\cdot \mathrm{h}$.

dehydrogenase was stimulated 22 to more than 100 times by the osmotic shock. In this latter case, the large stimulation on breaking the plastids results from the fact that the NADPH, that is necessary for the enzyme reaction, is unable to penetrate through the chloroplast envelope of the intact plastids ${ }^{23,46}$.

Further evidence of the resistance of the chloroplast envelope to some of the reactants in the two transaminase reactions is given in Figs. 4, 5 and 6. In these instances, the intact plastids were broken by ultrasonic vibration in the vessel after the reaction had been initiated. The change in slope represents the stimulation due to the breaking of the intact plastids. Treatment of the osmotically swollen chloroplasts with ultrasonic vibration gave little or no stimulation of the reactions while treatment of

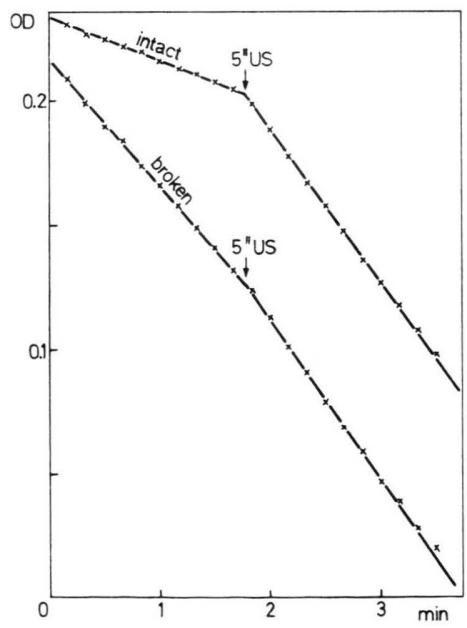

Fig. 4. The activity of glutamate-pyruvate transaminase in suspensions of intact and broken spinach chloroplasts before and after treatment with ultrasonic vibration (US). Abscissa: time in min. Ordinate: optical density as measured with a Zeiss spectrophotometer. $25 \mu \mathrm{g}$ chlorophyll per $\mathrm{ml}$ isotonic reaction medium in the cuvette.

46 U. Heber and K. A. Santarius, Biochim. biophysica Acta [Amsterdam] 109, 390 [1965].

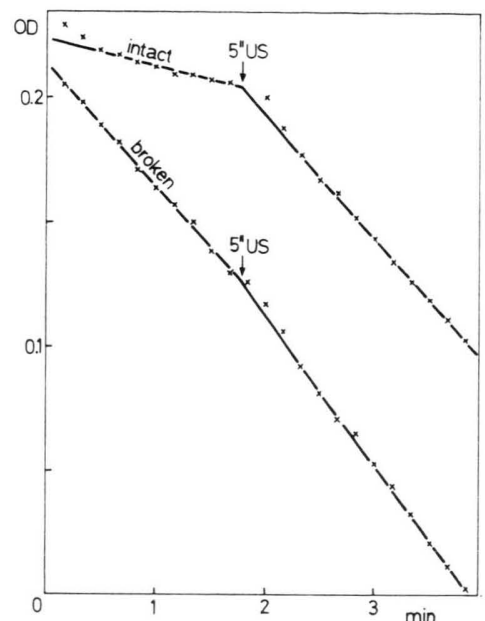

Fig. 5. The activity of glutamate-oxaloacetate transaminase in suspensions of intact and broken spinach chloroplasts before and after treatment with ultrasonic vibration (US). Abscissa: time in min. Ordinate: optical density as measured with a Zeiss spectrophotometer. $10 \mu \mathrm{g}$ chlorophyll per $\mathrm{ml}$ isotonic reaction medium in the cuvette.

the "intact" (a mixture of intact and broken) plastids did. These results indicate that the chloroplast envelope acted as a partial barrier to the passage of at least one or more of the reactants in each transaminase reaction in vitro (glutamate, pyruvate, $\alpha$-ketoglutarate, alanine and glutamate, oxaloacetate, $\alpha$-ketoglutarate, aspartate). However, all of these compounds must have been able to pass through the chloroplast envelope at significant rates since in no case was the stimulation on plastid rupture comparable to that observed when exogenous NADPH was one of the reactants. The possible influence of the isolation procedure and the suspending buffer medium on the permeability of the plastid envelope cannot be evaluated in these experiments. 


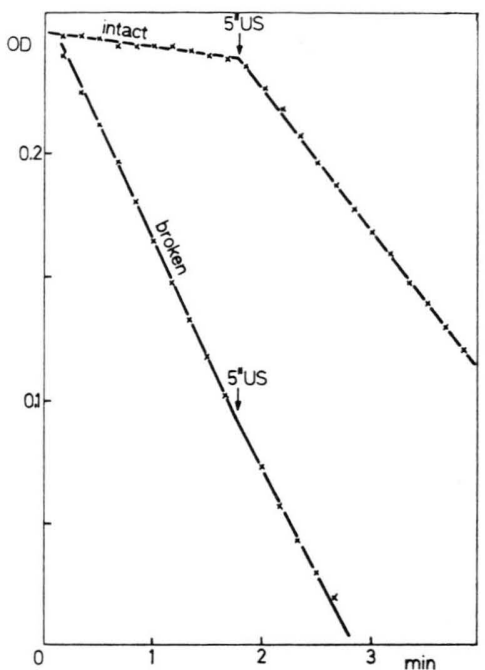

Fig. 6. The activity of NADP-dependent glyceraldehyde-3phosphate dehydrogenase in suspensions of intact and broken spinach chloroplasts before and after treatment with ultrasonic vibration (US). Abscissa: time in min. Ordinate: optical density as measured with a Zeiss spectrophotometer. $5 \mu \mathrm{g}$ chlorophyll per $\mathrm{ml}$ isotonic reaction medium in the cuvette.

5. Conclusions concerning the synthesis of amino acids within the chloroplasts of leaf cells

The present experiments confirm and extend earlier reports that the chloroplasts contain the essential metabolic machinery for the synthesis of some of the most common amino acids.

According to BASSHAM and KIRK ${ }^{47}$ the incorporation of inorganic nitrogen into organic compounds

47 J. A. Bassham and M. KIRK, Biochim. biophysica Acta [Amsterdam] 90, 553 [1964]. occurs in Chlorella via glutamic acid. They postulated that the reductive amination to form glutamic acid is the primary route for the incorporation of inorganic nitrogen during photosynthesis and assumed that the amino groups in the other amino acids could all have arisn by transamination of their respective keto acids with glutamic acid acting as the amino donor. Our experiments have demonstrated the presence of aspartic dehydrogenase as well as glutamic dehydrogenase in chloroplasts. Consequently the possibility of the formation of aspartic acid from oxaloacetate by reductive amination cannot be ruled out in this tissue. Glutamate-oxaloacetate transaminase and glutamate-pyruvate transaminase were both present in relatively high concentrations in chloroplasts. However, we were unable to detect in plastids any transaminases capable of transferring the amino group from either glutamic acid or aspartic acid to either hydroxypyruvate or glyoxylate. Hence, at least in our in vitro experiments the glycolate pathway for the synthesis of serine and glycine as described for instance by RABSON et al. ${ }^{48}$ was not detected. The pathways for serine and glycine formation in chloroplasts cannot be determined from the results of our experiments.

The authors wish to thank Dr. U. Heber for his helpful discussions. This research was supported in part by a National Science Foundation grant GB$5342 \mathrm{X}$.

48 R. Rabson, N. E. Tolbert, and P. C. Kearney, Arch. Biochem. Biophysics 98, 154 [1962]. 